\title{
AGONIST-DEPENDENT PHOSPHORYLATION OF CEREBRAL AND ATRIAL MUSCARINIC RECEPTORS: BLOCKADE OF THE PHOSPHORYLATION BY GTP-BINDING REGULATORY PROTEINS AND ITS REVERSAL BY GUANINE NUCLEOTIDES
}

\author{
Kazuko Haga and Tatsuya Haga \\ Department of Biochemistry, Institute of Brain Research, Faculty of Medicine, University of Tokyo, \\ Hongo, Bunkyoku, Tokyo 113, Japan
}

\begin{abstract}
A kinase which phosphorylates muscarinic receptors depending on the presence of agonist was partially purified from porcine brain according to a purification procedure of the $\beta$-adrenergic receptor kinase (1). Muscarinic receptors purified from porcine atrium or cerebrum were phosphorylated only in the presence of agonist (carbamylcholine) and the effect of $1 \mathrm{mM}$ carbamylcholine was antagonized by 10 $\mu \mathrm{M}$ atropine. The phosphorylation was not affected by cAMP or cGMP, did not require the presence of $\mathrm{Ca}^{2+}$ and was inhibited by $0.15 \mathrm{M} \mathrm{NaCl}$ or $\mathrm{KCl}$, which indicated that the relevant kinase is the $\beta$-adrenergic receptor kinase itself or a similar kinase. When atrial or cerebral receptors were reconstituted with $\mathrm{G}$ proteins (Go) in phospholipid vesicles, the phosphorylation of receptors was not detected even in the presence of carbamylcholine but was detected in the presence of both guanine nucleotides and carbamylcholine. Both GTP and GDP had the effect to restore the phosphorylation of receptors. These results are consistent with an idea that the ternary complex of agonist-receptor-G protein is formed in the absence of both GTP and GDP thereby masking the phosphorylation site on muscarinic receptors.
\end{abstract}

The muscarinic acetylcholine receptor is a member of a family of receptors with putative seven transmembrane segments and at least five different receptor subtypes $(\mathrm{m} 1-\mathrm{m} 5)$ have been known (see reviews $4,7,15,18$ ). The function of muscarinic receptors is believed to be the activation of GTP-binding regulatory proteins ( $G$ proteins), and direct evidence for the interaction between muscarinic receptors and $\mathrm{G}$ proteins has been obtained by reconstituting muscarinic receptors purified from porcine atrium (m2 subtype) or cerebrum (predominantly $\mathrm{m} 1$ subtype) with $\mathrm{G}$ proteins purified from cerebrum (Gi, Go, or $\mathrm{Gn}$ ) or atrium $(6,19)$. Muscarinic receptors as well as other receptors are known to be desensitized by prolonged incubation with agonists and it is assumed that the phosphorylation of muscarinic receptors is involved in the process of desensitization (for review, see 13).

Muscarinic receptors purified from porcine cerebrum (8) or atrium (16) have been shown to be phosphorylated by cAMP-dependent protein kinase. Cerebral muscarinic receptors were also phosphorylated by protein kinase $\mathrm{C}$ but atrial receptors were not (7; and unpublished data). The function of these phosphorylations is not known and the interaction between purified receptors and $G$ proteins in phospholipid vesicles was not affected by the 
phosphorylation as far as examined so far (7). In addition, these phosphorylations were observed irrespective of the presence or absence of agonist. On the other hand, Kwatra et al. $(11,12)$ reported that muscarinic receptors of chick heart were phosphorylated in vivo depending on the presence of agonists and suggested that the phosphorylation was involved in homologous desensitization of muscarinic receptors. Rhodopsin $(17,20)$ and $\beta$-adrenergic receptor (1), which are members of the $G$ protein-linked receptor family, have been shown to be phosphorylated by rhodop$\sin$ kinase or $\beta$-adrenergic receptor kinase depending on the exposure to light or on addition of $\beta$ agonists.

In the present paper, we report that muscarinic receptors purified from cerebrum or atrium are phosphorylated depending on the presence of an agonist by a kinase which is similar to or the same as the $\beta$ adrenergic receptor kinase and that the phosphorylation is affected by $\mathrm{G}$ proteins in a guanine nucleotide-sensitive manner.

\section{MATERIALS AND METHODS}

Reconstitution of Muscarinic Receptors with $G$ Proteins

Muscarinic receptors were purified from porcine atrium (14) or cerebrum (5) and reconstituted with Go purified from porcine cerebrum in phospholipid vesicles as described previously (6).

\section{Phosphorylation Reaction}

A kinase preparation was pre-incubated with $2 \mu \mathrm{M}$ ATP in a buffer solution $(20 \mathrm{mM}$ Tris-HCl, $\mathrm{pH} 7.5 / 2 \mathrm{mM}$ EDTA/5 $\mathrm{mM} \mathrm{MgCl}_{2}$; total volume, $0.1 \mathrm{ml}$ ) for $30 \mathrm{~min}$ at $30^{\circ} \mathrm{C}$ and then the buffer solution containing muscarinic receptors $(1-2 \mathrm{pmol})$ incorporated into phospholipid vesicles, carbamylcholine and $\left[{ }^{32} \mathrm{P}\right] \mathrm{ATP}\left(10^{6} \mathrm{cpm} / \mathrm{tube}\right)$ were added (final volume, $0.2 \mathrm{ml}$ ). In some experiments, muscarinic receptors were reconstituted with $G$ protein (Go or Gi) of 5-10 times as much as receptors and then subjected to phosphorylation in the presence or absence of guanine nucleotides. The mixture was incubated for 0-60 min, then diluted with $2 \mathrm{ml}$ of a buffer solution $(20 \mathrm{mM}$ Hepes-KOH, pH $8 / 1 \mathrm{mM}$
EDTA/0.16 $\mathrm{M} \mathrm{NaCl}$ ) and the mixture was centrifuged for $30 \mathrm{~min}$ at $190,000 \mathrm{~g}$. The pellet was suspended in a solution containing $2.5 \%$ sodium dodecyl sulfate (SDS) $(50 \mu \mathrm{l})$ and a portion was subjected to sodium dodecyl sulfate-polyacrylamide gel electrophoresis (SDSPAGE) (acrylamide concentration, 10\%) followed by autoradiography. The band of muscarinic receptors were cut and counted with Cerenkov method.

\section{Partial Purification of Kinase}

The procedure used for purification of the $\beta$ adrenergic receptor kinase (1) was used with a slight modification. Porcine cerebrum (200 g) was homogenized in a buffer solution A (20 $\mathrm{mM}$ Tris- $\mathrm{HCl}$, pH 7.5/5 mM EDTA/5 mM EGTA/1 mM phenylmethylsulfonyl fluoride/ $20 \mu \mathrm{g} / \mathrm{ml}$ benzamidine $/ 10 \mu \mathrm{g} / \mathrm{ml}$ pepstatin; 1 1) with Waring blender and Physcotron and then centrifuged for $20 \mathrm{~min}$ at $63,000 \mathrm{~g}$. Ammonium sulfate was added to the supernatant to $30 \%$ and then the precipitate was collected by centrifugation and suspended in the solution A $(90 \mathrm{ml})$. The suspension was applied to Ultrogel AcA 34 column (4.6x $71 \mathrm{~cm}, 1.2 \mathrm{l}$ ), which had been equilibrated with buffer solution B $(20 \mathrm{mM}$ Tris- $\mathrm{HCl}$, $\mathrm{pH}$ 7.5/2 mM EDTA/2 mM EGTA/0.1 mM phenylmethylsulfonyl fluoride $/ 10 \mu \mathrm{g} / \mathrm{ml}$ benzamidine $/ 5 \mu \mathrm{g} / \mathrm{m}$ l pepstatin), and the fraction with muscarinic receptor-phosphorylating activity was collected. The fraction was applied to the column linked in tandem [DEAE-Sephacel $(10 \mathrm{ml})$ and CM-Toyopearl $(8 \mathrm{ml})$ ] which had been equilibrated with the solution B. The muscarinic receptor-phosphorylating activity was not detected in the flow-through fraction. Muscarinic receptors were phosphorylated by the fraction eluted from DEAE-Sephacel but the phosphorylation was independent of the presence of agonist. Agonist-dependent phosphorylation of muscarinic receptors was found in the fraction eluted from CM-Toyopearl with a linear gradient of $\mathrm{NaCl}(0-120 \mathrm{mM} \mathrm{NaCl}, 40 \times 40 \mathrm{ml})$ in buffer solution $\mathrm{C}(20 \mathrm{mM}$ Tris- $\mathrm{HCl}, \mathrm{pH}$ 7.5/1 mM EDTA/0.1 mM phenylmethylsulfonyl fluoride $/ 10 \mu \mathrm{g} / \mathrm{ml}$ benzamidine $/ 5 \mu \mathrm{g} /$ $\mathrm{ml}$ pepstatin). The maximal activity was eluted at approximately $80 \mathrm{mM} \mathrm{NaCl}$. This fraction was used in the present experiment. 


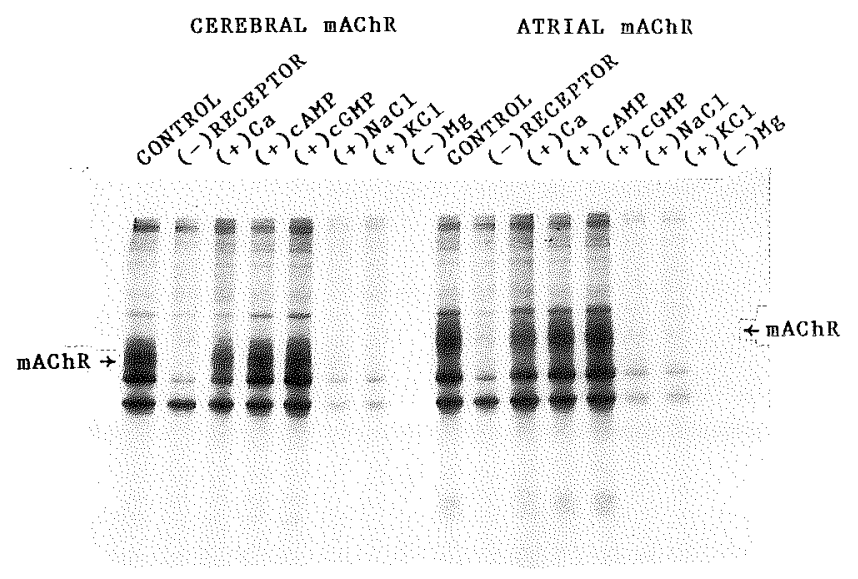

Fig. 1 Effects of several reagents on phosphorylation of muscarinic receptors. Muscarinic receptors, which were purified from porcine cerebrum or atrium and then incorporated into phospholipid vesicles, were phosphorylated with a kinase which was partially purified from porcine brain according to the purification procedure for the $\beta$-adrenergic receptor kinase (1). Control medium contained $20 \mathrm{mM}$ Tris-HCl (pH 7.5), $2 \mathrm{mM}$ EDTA, $5 \mathrm{mM} \mathrm{MgCl}, 1 \mu \mathrm{M}\left[{ }^{32} \mathrm{P}\right] \mathrm{ATP}\left(10^{6} \mathrm{cpm} /\right.$ tube), $1 \mathrm{mM}$ carbamylcholine, and muscarinic receptors in phospholipid vesicles (1-2 pmol). When indicated, $0.5 \mathrm{mM} \mathrm{Ca}^{2+}$ (in a free form), $0.1 \mathrm{mM}$ cAMP, $0.1 \mathrm{mM}$ cGMP, $0.15 \mathrm{M} \mathrm{NaCl}$, or $0.15 \mathrm{M} \mathrm{KCl}$ was present. Incubation was carried out for $60 \mathrm{~min}$ at $30^{\circ} \mathrm{C}$, and then $\left[{ }^{32} \mathrm{P}\right]$-phosphorylated components were collected in the pellet, dissolved in SDS solution and subjected to SDS-PAGE and autoradiography. See Materials and Methods for further details.

\section{RESULTS}

\section{Identification of Phosphorylated Bands}

Fig. 1 shows phosphorylated bands on SDSPAGE when purified cerebral or atrial muscarinic receptors were subjected to phosphorylation by the kinase preparation. The bands of muscarinic receptors were identified by their apparent molecular sizes and characteristic broadness. Apparent molecular size of atrial receptors was approximately $75 \mathrm{~K}$ and higher than that of cerebral receptors (approximately $70 \mathrm{~K}$ ). The identification of receptor bands was confirmed by the observation that no such bands were detected in control experiments where the receptor preparation was not added (Fig. 1). Several bands other than muscarinic receptors were detected without addition of receptor preparations and are considered to be contaminants in the kinase preparation. No phosphorylation was detected without addition of the kinase preparation, excluding the possibility that the kinase was copurified with the receptor (data not shown).

\section{Effects of Several Reagents}

The phosphorylation was not affected by
$0.1 \mathrm{mM}$ cAMP or cGMP (Fig. 1). The phosphorylation reaction required the presence of $\mathrm{Mg}^{2+}$ but not of $\mathrm{Ca}^{2+}$. Addition of $\mathrm{Ca}$ at a concentration of $0.5 \mathrm{mM}$ in a free form suppressed the phosphorylation appreciably and addition of $0.15 \mathrm{M} \mathrm{NaCl}$ or $\mathrm{KCl}$ greatly reduced the phosphorylation. The effect of these ions was observed in the phosphorylation of both receptors and contaminated proteins, indicating that this reflects the property of the enzyme rather than the substrate. A very similar effect of ions has been reported for the phosphorylation of $\beta$ adrenergic receptors by the $\beta$ adrenergic receptor kinase (1). These results indicate that the present activity is not due to cAMP- or cGMP-dependent kinase, protein kinase $\mathrm{C}$ or calmodulin-dependent kinase but is due to the $\beta$ adrenergic receptor kinase itself or to a very similar protein kinase.

\section{Effects of Carbamy/choline and Atropine}

Fig. 2 shows the effect of concentrations of carbamylcholine and atropine on the phosphorylation of cerebral or atrial muscarinic receptors. The phosphorylation of both atrial and cerebral muscarinic receptors increased with the carbamylcholine concentration 


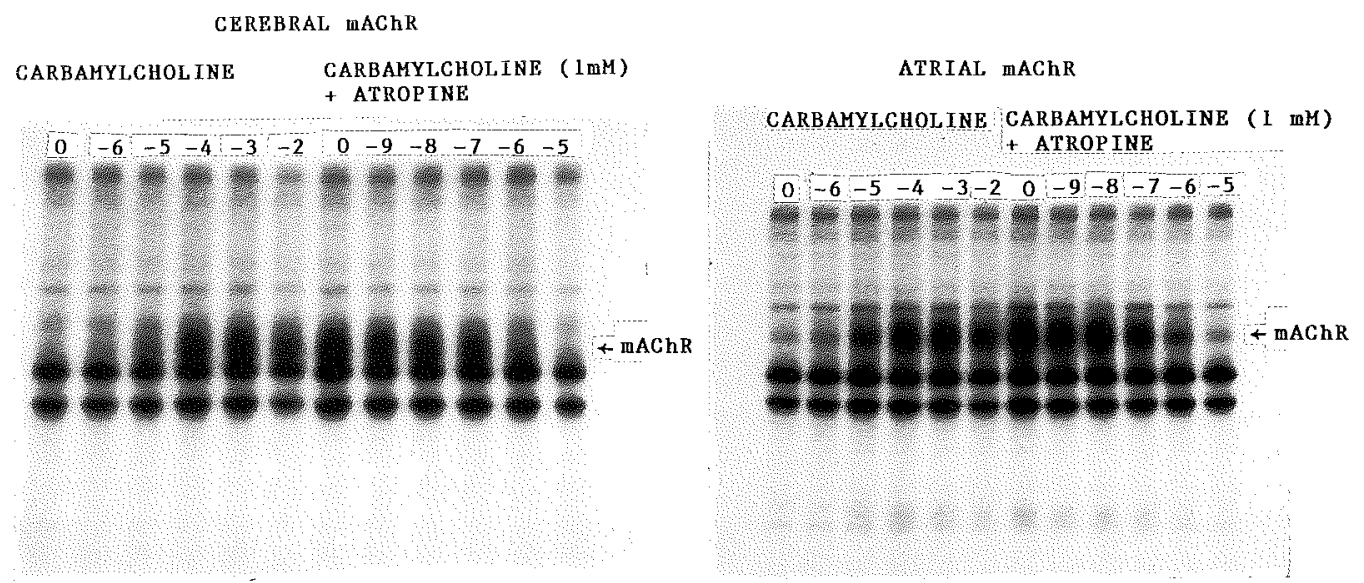

Fig. 2 Effects of carbamylcholine and atropine on the phosphorylation of muscarinic receptors. Experimental conditions were the same as those described in the legend to Fig. 1, except that concentrations of carbamylcholine and atropine were varied. Concentrations in logarithm of carbamylcholine and atropine are given on top of the lane.

except a slight decrease at $10 \mathrm{mM}$. The phosphorylation of muscarinic receptors in the presence of $1 \mathrm{mM}$ carbamylcholine decreased with the atropine concentration. Phosphorylation of cotaminated proteins was not affected by carbamylcholine or atropine except a slight decrease in the presence of $10 \mathrm{mM}$ carbamylcholine indicating that these reagents affected the substrate but not the enzyme. Muscarinic receptors appeared not to be phosphorylated in the absence of carbamylcholine or in the presence of excess atropine, but it could not be determined strictly whether the faint bands observed under these conditions are due to phosphorylation of muscarinic receptors or that of contaminated proteins. The concentration of carbamylcholine giving a half maximal effect was approximately $10 \mu \mathrm{M}$.

\section{Effects of G Proteins and Guanine Nucleotides}

When cerebral or atrial receptors were reconstituted with $\mathrm{G}$ proteins (Go) and then used as substrates for the kinase reaction, the phosphorylation of muscarinic receptors was not detected irrespective of the presence or absence of carbamylcholine (Fig. 3). The phosphorylation of receptors became to be detected when the phosphorylation reaction was carried out in the presence of both $10 \mu \mathrm{M}$
GTP $\gamma \mathrm{S}$ and carbamylcholine. The $\alpha$ - and $\beta$ subunits of $\mathrm{G}$ proteins were not phosphorylated by this kinase, in contrast to protein kinase $\mathrm{C}$ (6). The phosphorylation of contaminated proteins was not affected by $G$ protein or guanine nucleotides indicating that they did not affect the kinase but affected the receptors. The degree of phosphorylation was greater when muscarinic receptors were reconstituted with $G$ proteins in lipid vesicles and then phosphorylated in the presence of GTP $\gamma \mathrm{S}$ rather than when muscarinic receptors alone were reconstituted in lipid vesicles and then phosphorylated. This reflects the higher recovery of muscarinic receptors in lipid vesicles in the presence of $\mathrm{G}$ proteins as compared in their absence.

GTP $\gamma \mathrm{S}$ could be replaced by either GTP or GDP. Fig. 4 shows the effect of concentrations of GTP or GDP on phosphorylation of atrial and cerebral receptors reconstituted with Go. The concentration giving a half maximal effect was approximately $0.3 \mu \mathrm{M}$ and $3 \mu \mathrm{M}$ for GTP and GDP, respectively.

\section{DISCUSSION}

The present results indicate that muscarinic receptors as well as rhodopsin and $\beta$-adrenergic receptors are phosphorylated depending on the presence of agonists by the $\beta$-adrenergic 
CEREBRAL MAChR

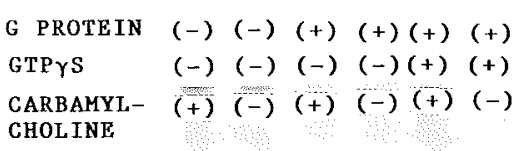

ATRIAL WAChR
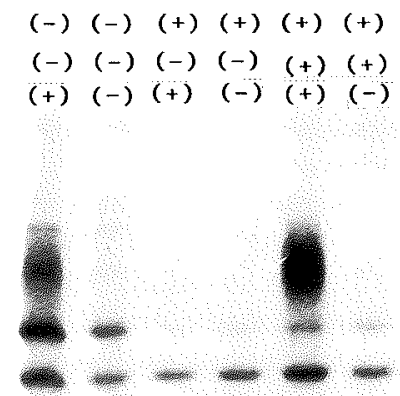

Fig. 3 Effects of $\mathrm{G}$ protein $(\mathrm{Go})$ and GTP $y \mathrm{~S}$ on phosphorylation of muscarinic receptors. Experimental conditions were the same as those described in the legend to Fig. 1 except that when indicated, G proteins were incorporated into phospholipid vesicles together with muscarinic receptors, $10 \mu \mathrm{M}$ GTP $\gamma \mathrm{S}$ was added, and $1 \mathrm{mM}$ carbamylcholine was replaced by $10 \mu \mathrm{M}$ atropine.
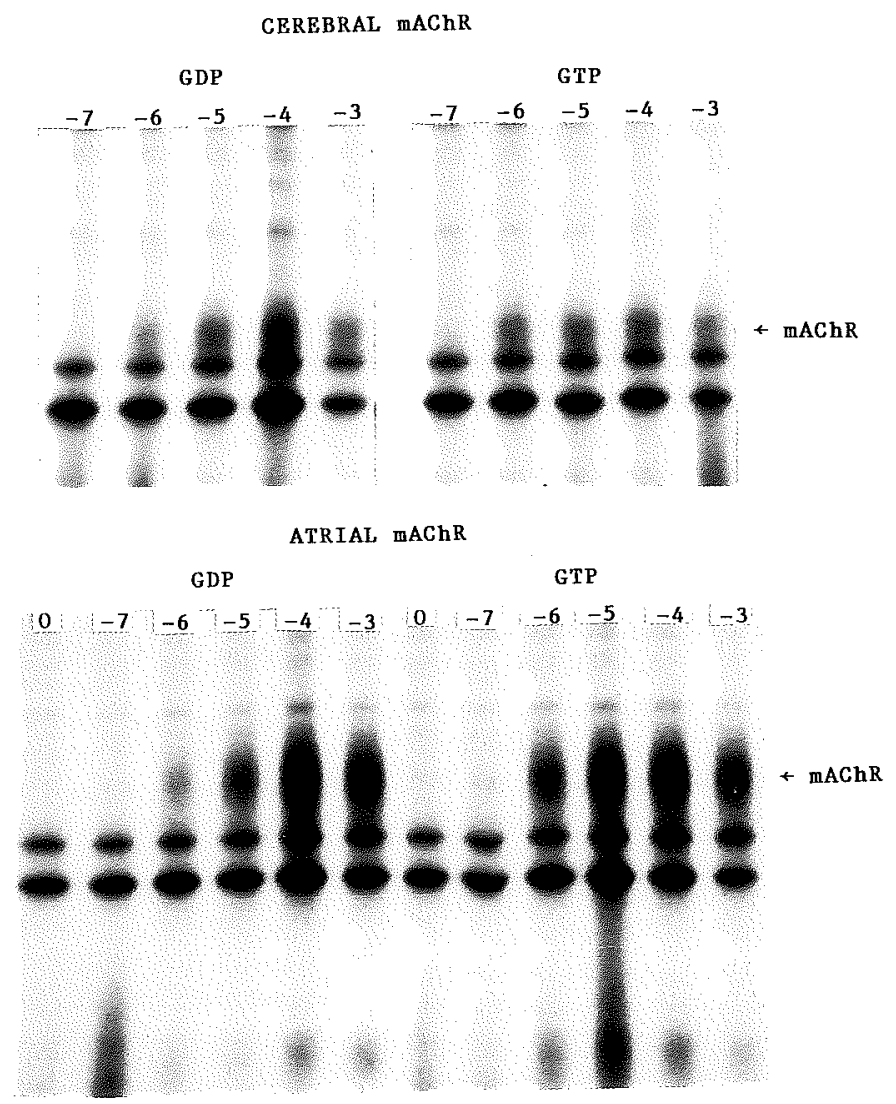

Fig. 4 Effect of concentrations of GTP or GDP on phosphorylation of cerebral or atrial muscarinic receptors. Experimental details are given in legends to Figs. 1 and 3 except that GTP $\gamma \mathrm{S}$ was replaced by various concentrations of GTP or GDP. Concentrations in logarithm of GTP or GDP are given on top of the lane. 
receptor kinase or by a very similar enzyme. While we were preparing the manuscript, Kwatra et al. (10) reported that muscarinic receptors in chick heart were phosphorylated by the $\beta$-adrenergic receptor kinase. Their results are consistent with ours.

Muscarinic receptors in heart are considered to be of $\mathrm{m} 2$ subtype because 1 ) the membrane receptors show a low affinity for pirenzepine and only $\mathrm{m} 2$ among five subtypes is known to show a low affinity for pirenzepine, and 2) only mRNA encoding $m 2$ has been detected in heart so far. On the other hand, cerebral muscarinic receptors may be composed of five subtypes because all mRNAs encoding the five subtypes have been detected in the brain. Approximately $20 \%$ of purified cerebral receptors are considered to be $\mathrm{m} 2$ because this fraction showed a low affinity for pirenzepine when purified receptors were incorporated into cerebral membranes (3). The major subtype in the remaining $80 \%$ is considered to be $\mathrm{ml}$ because major peptides in partial hydrolysates of purified receptors were those of $\mathrm{ml}$ and peptides corresponding to $\mathrm{m} 3, \mathrm{~m} 4$ and $\mathrm{m} 5$ were not detected (9). These facts, together with the finding that the degree of phosphorylation per receptor is similar between atrial and cerebral receptors, suggest that $\mathrm{m} 1$ as well as $\mathrm{m} 2$ are phosphorylated by the present kinase. The finding that apparent sizes of phosphorylated bands are different between atrial and cerebral receptors is also consistent with the above assumption, although there is a possibility that the amount of bound sugar is different between cerebral and atrial $\mathrm{m} 2$. The strict determination of subtype specificity of the kinase should be performed by using a single subtype expressed from a single cDNA or gene.

Benovic et al. (2) reported that the $\beta$-adrenergic receptor kinase phosphorylated $\alpha_{2}$ but not $\alpha_{1}$-adrenergic receptor. The $\alpha_{2^{-}}$and $\alpha_{1^{-}}$ adrenergic receptors are known to be linked to inhibition of adenylate cyclase and activation of polyphosphatidylinositol phospholipase C, respectively. The $m 2$ subtype is also known to be linked to inhibition of adenylate cyclase. It was suggested that the $\beta$-adrenergic receptor kinase may be specific to receptors linked to adenylate cyclase $(2,10)$. On the other hand, $\mathrm{m} 1$ has been reported to be linked to activation of polyphosphatidylinositol phospholi- pase $C$ (see reviews 4,18 ). It is possible that $\mathrm{m} 1$ and $\mathrm{m} 2$ are phosphorylated by similar but distinct kinases. It remains to be known if there are several kinds of receptor kinases which are specific to a certain group of receptors.

The phosphorylation of muscarinic receptors was inhibited by reconstituting $\mathrm{G}$ proteins with receptors in lipid vesicles (Fig. 3) and the inhibition was suppressed by addition of GTP or GDP (Fig. 4). These results are consistent with an idea that the phosphorylation site in muscarinic receptors becomes buried by the formation of agonist-receptor- $\mathrm{G}$ protein complex and then exposed by the dissociation of the complex into agonist-receptor and $G$ protein-GTP or $G$ protein-GDP on addition of GTP or GDP. This suggests that the phosphorylation site is very near to the Gprotein binding site. It remains to be elucidated if the phosphorylation may affect the interaction of the receptor with $G$ proteins.

This study was supported by Grants-in-Aid from the Ministry of Education, Science and Culture, Japan and a grant from the Nissan Science foundation.

\section{Received for publication 19 June 1989}

\section{REFERENCES}

1. Benovic J. L., Mayor F., Staniszewsiki C. LEFKowitz R. J. and CARON M. G. (1987) Purification and characterization of the $\beta$-adrenergic receptor kinase. J. Biol. Chem 262, 9026-9032

2. Benovic J. L., Regan J.W., Matsui H., Mayor F., Cotecchia S., Leeb-LundBerg L. M. F., Caron M. G. and Lefkowitz R. J. (1987) Agonist-dependent phosphorylation of the $\alpha_{2}$ adrenergic receptor by the $\beta$-adrenergic receptor kinase. J. Biol. Chem. 262, 17251-17253

3. Berstein G., Haga T. and Ichiyama A. (1989) Effect of the lipid environment on the differential affinity of purified cerebral and atrial muscarinic acetylcholine receptors for pirenzepine. Mol. Pharmacol. (in press)

4. Bonner T. I. (1989) The molecular basis of muscarinic receptor diversity. Tiends Pharmacol. Sci. 12, 148-151

5. HAGA K. and HaGA T. (1985) Purification of the muscarinic acetylcholine receptor from porcine brain. J. Biol. Chem. 260, 7927-7935

6. Haga K., Uchiyama H., Haga T., Ichiyama A., Kangawa K. and Matuo H. (1989) Cerebral 
muscarinic acetylcholine receptors interact with three kinds of GTP-binding proteins in a reconstitution system of purified components. Mol. Phamacol. 35, 286-294

7. Haga T., Haga K., Berstein G., Nishiyama T., UCHIYAMA H., and ICHIYAMA A. (1988) Molecular properties of muscarinic receptors. Trends Pharmacol. Sci. Suppl., Subtypes of Muscarinic Receptors III, 12-18

8. Ho A. K. S., Ling Ol-L., Duffield R., LAM P. H, and WANG J. H. (1987) Phosphorylation of brain muscarinic receptor: Evidence of receptor regulation. Biochem. Biophys. Res. Commun. $142,911-918$

9. Kubo T., Fukuda K., Mikami A., Maeda A., Takahashi H., Mishina M., Haga T., HaGa K., ICHIYAMA A., KangawA K., KoJma M., Matsuo H., Hirose T. and Numa S. (1986) Cloning, suquencing and expression of complementary DNA encoding the muscarinic acetylcholine receptor. Nature 323, 411-416

10. Kwatra M. M., Benovic J. L., Caron M. G., Lefkowitz R. J. and Hosey M. M. (1989) Phosphorylation of chick heart muscarinic cholinergic receptors by the $\beta$-adrenergic receptor kinase. Biochemistry 28, 4543-4547

11. Kwatra M. M. and Hosey M. M. (1986) Phosphorylation of the cardiac muscarinic receptor in intact chick heart and its regulation by a muscarinic agonist. J. Biol. Chem. 261, 1242912432

12. Kwatra M. M., Leung E., MaAn A. C., McMahon K. K., Ptasienski J., Green R. D. and Hosey M. M. (1987) Correlation of agonistinduced phosphorylation of chick heart muscarinic receptors with receptor desensitization $J$. Biol. Chem. 262, 16314-16321
13. Nathanson M. M. (1987) Molecular properties of the muscarinic acetylcholine receptor. $A n n$. Rev. Neurosci. 10, 195-236

14. Nishiyama T., Berstein G., Ikegaya T., HaGa T., IChIy ama A., Kobayashi A. and Yamazaki N. (1989) Comparison between purified cerebral and atrial muscarinic acetylcholine receptors: Pirenzepine binding and the effect of sulfhydryl reagents. Biomedical Res. 10, 251-260

15. Peralta E. G., Winslow J. W., Ashienazl A., Smith D. H., Remachandran J. and CAPON D. J. (1988) Structural basis of muscarinic acetylcholine receptor subtype diversity. Trends Pharmacol. Sci. Suppl., Subtypes of Muscarinic Receptors III, 6-11

16. Rosenbaum L.C., Malencik D. A., Anderson S. R., Tota M. R. and SchimerLik M. I. (1987) Phosphorylation of the porcine atrial muscarinic acetylcholine receptor by cyclic AMP dependent protein kinase. Biochemistry 26, 81838188

17. Schichi H. and Sommers R. L. (1978) Lightdependent phosphorylation of rhodopsin: Purification and properties of rhodopsin kinase. $J$. Biol. Chem. 253, 7040-7046

18. SCHIMERLiK M. I. (1989) Structure and regulation of muscarinic receptors. Ann. Rev. Physiol. 51, 217-227

19. Tota M. R., Kahler K. R. and Schimerlik M. I. (1987) Reconstitution of the purified porcine atrial muscarinic acetylcholine receptor with purified porcine atrial inhibitory guanine nucleotide binding protein. Biochemistry $\mathbf{2 6}, 8175-$ 8182

20. WILDEN U. and KÜN H. (1982) Light-dependent phosphorylation of thodopsin: Number of phosphorylation sites. Biochemistry 21, 3014-3022 